๑ Open Access Full Text Article

CORRIGENDUM

\title{
Synthesis, Characterization, and in vitro Evaluation of Curcumin-Loaded Albumin Nanoparticles Surface-Functionalized with Glycyrrhetinic Acid [Corrigendum]
}

Li J, Chen T, Deng F, et al. Int J Nanomedicine. 2015;10 (1):5475-5487.

The authors have advised Figure 7 on page 5482 is incorrect. The authors inadvertently included duplicate images for the panels shown in Before treatment A and C, After treatment $\mathrm{B}$ and $\mathrm{C}$ and For attachment $\mathrm{D}$ and $\mathrm{E}$. The correct Figure 7 is as follows. 


\section{For attachment}

A

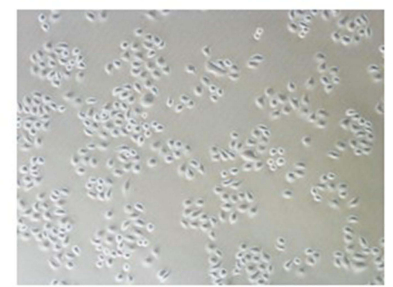

B
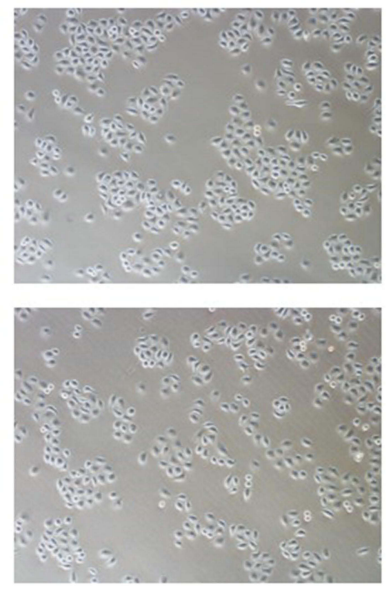

C
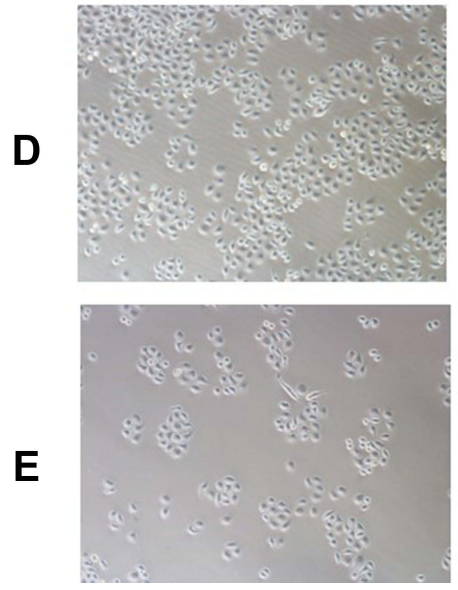

Before treatment
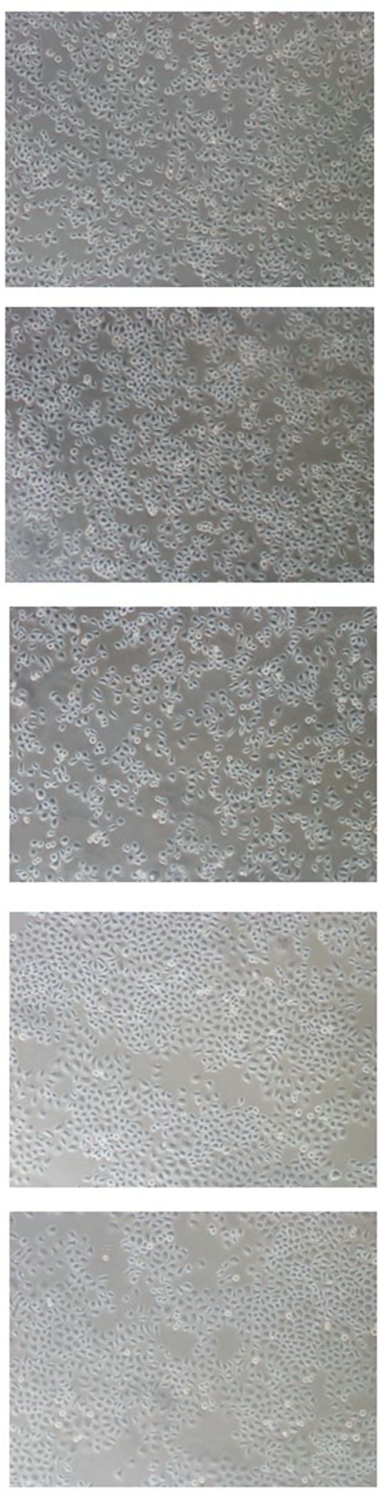

After treatment
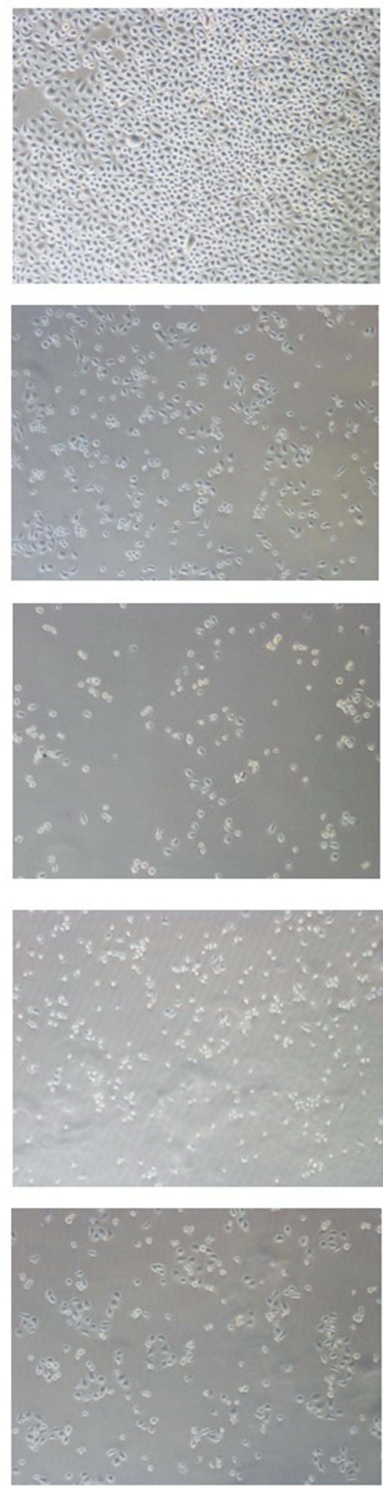

Figure 7 Photographs of HepG2 cells treated with curcumin suspension, curcumin-loaded albumin nanoparticles, curcumin-loaded albumin nanoparticles surfacefunctionalized with GA, and GA + curcumin-loaded albumin nanoparticles surface-functionalized with GA for 24 hours.

Notes: (A) Control; (B) Ccn-sus; (C) Ccn-BNPs; (D) Ccn-BNP-GA; (E) GA+Ccn-BNP-GA.

Abbreviations: Ccn-sus, curcumin suspension; Ccn-BNPs, curcumin-loaded albumin nanoparticles; Ccn-BNP-GA, curcumin-loaded albumin nanoparticles surface-functionalized with GA; GA, glycyrrhetinic acid.

\section{Publish your work in this journal}

The International Journal of Nanomedicine is an international, peerreviewed journal focusing on the application of nanotechnology in diagnostics, therapeutics, and drug delivery systems throughout the biomedical field. This journal is indexed on PubMed Central, MedLine, CAS, SciSearch ${ }^{\mathbb{B}}$, Current Contents ${ }^{\mathbb{B}} /$ Clinical Medicine, $^{2}$
Journal Citation Reports/Science Edition, EMBase, Scopus and the Elsevier Bibliographic databases. The manuscript management system is completely online and includes a very quick and fair peer-review system, which is all easy to use. Visit http://www.dovepress.com/ testimonials.php to read real quotes from published authors. 